\title{
Renewable Diesel Fuel from Processing of Vegetable Oil in Hydrotreatment Units: Theoretical Compliance with European Directive 2009/28/EC and Ongoing Projects in Spain
}

\author{
Daniel Garraín, Israel Herrera, Carmen Lago, Yolanda Lechón, Rosa Sáez \\ Spanish Ministry of Science and Innovation, CIEMAT (Public Research Centre on Energy, Environment and Technologies), Energy \\ Department, Energy Systems Analysis Unit, Madrid, Spain. \\ Email: daniel.garrain@ciemat.es
}

Received August $2^{\text {nd }} 2010$; revised August $5^{\text {th }} 2010$; accepted August $10^{\text {th }} 2010$.

\begin{abstract}
Oil hydrotreating units in refineries are aimed at reducing the sulfur content of fuels to accomplish standard particular specifications. However, this process is currently one of the best available technologies to produce biofuels from vegetable oil in a refinery. Vegetable oils can be processed or co-processed in these units if several adaptations are performed, so some properties could be improved in comparison with conventional fuel such as density and cetane number. This study highlights the theoretical greenhouse gases (GHG) emissions (using a life cycle assessment-LCA-approach) of a hydrotreated vegetable oil (HVO) from bibliographical data. Results were compared with other biofuel production processes, such as those obtained by transesterification of vegetable oil (FAME, fatty acid methyl ester). It has also been included the comparison with conventional fossil diesel as a benchmark in order to assess the theoretical compliance with GHG savings proposed in European Directive 2009/28/EC. Finally, ongoing projects and future perspectives in Spain are mentioned.
\end{abstract}

Keywords: Hydrotreated Vegetable Oil, Fatty Acid Methyl Ester, GHG Emissions Savings, Directive 2009/28/EC, Renewable Diesel Fuel

\section{Introduction}

Oil hydrotreating units in refineries are aimed at reducing the sulphur content of fuels to accomplish standard particular specifications. However, hydrotreating of vegetable oils or animal fats is an alternative process to esterification for producing biobased diesel fuels. This practice is a modern way to produce very high-quality biobased diesel fuels without compromising fuel logistics, engines, exhaust aftertreatment devices, or exhaust emissions. These fuels (hydrotreated vegetable oils-HVO-) are now also referred to as 'renewable diesel fuels' instead of esterificated 'biodiesel' which is reserved for the fatty acid methyl esters (FAME) [1].

Selected FAME and HVO properties have been compared in Table 1 since they represent two different approaches for making diesel fuel from vegetable oil. HVO has excellent diesel fuel properties including an extremely high cetane number (measure of a diesel fuel's ignition delay). FAME has lower heating value (LHV) because of its oxygen content and also has other undesirable properties such as high density, and high $\mathrm{NO}_{\mathrm{x}}$ emissions. Overall, HVO appears to be a superior product [2].

This paper focuses on the greenhouse gas (GHG) emissions study of a theoretical HVO process, from bibliographical data, to identify problematic stages in the production chain in order to reduce environmental impacts. For this evaluation, life cycle assessment (LCA) methodology was the approach chosen to calculate the GHG emissions profile associated with the production of this new renewable diesel fuel.

ISO 14040:2006 and ISO 14044:2006 standards [4,5] define LCA as a methodology for the comprehensive assessment of the impact that a product or process has on the environment throughout its life span (from extraction of raw materials through manufacturing, logistics and use to scrapping and recycling, if any), which is known as a 
Table 1. Comparison of FAME and HVO properties [1-3]

\begin{tabular}{lcc}
\hline \multicolumn{1}{c}{ Properties } & FAME & HVO \\
\hline \% Oxygen & 11 & 0 \\
Density $\left(15^{\circ} \mathrm{C}\right)(\mathrm{g} / \mathrm{ml})$ & 0.883 to 0.885 & 0.775 to 0.780 \\
Viscosity $\left(40^{\circ}\right)\left(\mathrm{mm}^{2} / \mathrm{s}\right)$ & 4.5 & 2.5 to 3.5 \\
Cloud point $\left({ }^{\circ} \mathrm{C}\right)$ & -5 to 0 & -5 to -30 \\
Sulphur content & $<10$ ppm & $<10 \mathrm{ppm}$ \\
LHV $(\mathrm{MJ} / \mathrm{kg})$ & 37.5 to 38 & 44 \\
Storage stability & Very challenging & Good \\
Cetane number & 50 to 65 & 80 to 99 \\
$\%$ change in $\mathrm{NO}_{\mathrm{x}}$ emission & +10 & 0 to -10 \\
\hline
\end{tabular}

"from cradle-to-grave" analysis.

\section{Goal and Scope}

The first step in a LCA is to define the scope and goals of the study. This work aims to assess the theoretical production of HVO from soybean under an LCA framework focused on the global warming impact category in order to calculate GHG emissions. Counterbalanced bibliographical data and previous own revisions were selected to study the process in detail. Results will be compared with other biofuel production processes, such as those obtained by transesterification of vegetable oil (FAME, fatty acid methyl ester). It will also be included the comparison with conventional fossil diesel as a benchmark in order to assess the theoretical compliance with GHG savings proposed in European Directive 2009/28/EC.

The scope of this assessment is cradle-to-grave, from acquisition of the raw materials in agricultural labours through the production of HVO in refinery to the final combustion. Stages taken into account are detailed in Table 2 of the following Section 3.

According to ISO 14040:2006 standard, the functional unit provides a reference to which inputs and outputs are normalised. In this case study, the amount of fuel expressed in energy units (MJ, Megajoules) was considered.

\section{Life Cycle Inventory}

\subsection{Data Collection}

Life cycle inventory (LCI) phase involves data collection and modeling of the product system, as well as description and verification of data. This encompasses all data related to environmental and technical quantities for all relevant unit processes within the study boundaries that compose the product system. The procedure for LCI of the HVO and FAME productions are summarised in Table 2 .

Inventory data for those energy and material inputs were obtained from eco-profiles within SimaPro7.1 software [11], representing average production in a European context.

\subsection{Allocation Procedures}

According to ISO 14044:2006 standard [5], allocation process is defining as the partitioning of the input/outputs flows of a process to the system product under study. The allocation procedure in a multi-product process is the most critical issue in LCA, so it is recommended avoiding allocation whenever possible either through subdivision of certain processes or by expanding the system limits to include the additional functions related to them. Where allocation cannot be avoided, the environmental loads could be assigned allocated into two or more sub

Table 2. Procedure of LCI of HVO and FAME production and data sources

\begin{tabular}{llll}
\hline \multicolumn{1}{c}{ Phase (product) } & \multicolumn{1}{c}{ Main input data } & Main output data & Data source \\
\hline Seed farming (HVO and FAME) & Pesticides, fertilizers, fuel & & Soybean meal \\
Oil extraction (HVO and FAME) & Hexane, electricity, natural gas & {$[6]$} & {$[6]$} \\
Oil refining (HVO and FAME) & $\begin{array}{l}\text { Caustic soda, aluminium sulphate, ammonia nitrate, bentonite, } \\
\text { electricity, natural gas }\end{array}$ & Soap pulp (waste) & {$[6]$} \\
Oil transesterification (FAME) & Chloride acid, catalyser, methanol, electricity, natural gas & Glycerol & Adapt.from [7] \\
Oil hydrotreating (HVO) & Hydrogen, electricity, steam & Naphta, ateam, electricity & {$[8]$} \\
Transports (HVO and FAME) & Distances, type of transport & - & {$[6,9,10]$} \\
Combustion (HVO and FAME) & - & - & {$[10]$} \\
\hline
\end{tabular}


processes or expanding the product system to include the additional functions related to co products. Oil extraction, transesterification and hydrotreating phases yield more than one product, therefore, allocation is necessary. Energy allocation was considered in the case because of the purpose of the main product.

\section{Results and Discussion}

\subsection{FAME vs HVO}

LCA was conducted by means of SimaPro v.7.1 software [11], using characterization factors from CML 2 baseline 2000 methodology [12]. Low heating values used has been $44.0 \mathrm{MJ} / \mathrm{kg}$ and $37.2 \mathrm{MJ} / \mathrm{kg}$, for $\mathrm{HVO}$ and FAME respectively. Table 3 shows the GHG emissions of both products by stage of the whole life cycle.

GHG emissions in the combustion phase are considered null due to the biogenic origin of the carbon in the plant. Total values of the table show that theoretical environmental benefits are achieved from the processing of vegetable oil with hydrogen against transesterification process to obtain biofuels.

\subsection{Compliance with European Directive 2009/28/EC}

European Directive 2009/28/EC establishes a common framework for the promotion of energy from renewable sources. It sets mandatory national targets for the overall share of energy from renewable sources in gross final consumption of energy and for the share of energy from renewable sources in transport. Article 17 refers to the sustainability criteria for biofuels and bioliquids, highlighting that the GHG emission saving from the use of biofuels and bioliquids shall be at least 35\%. With effect from January $1^{\text {st }} 2017$, that saving shall be at least $50 \%$, and from January $1^{\text {st }} 2018$, shall be at least $60 \%$ for biofuels and bioliquids produced in installations in which production started on or after January $1^{\text {st }} 2017$. For biofuels, for the purposes of the calculation referred to GHG savings, the fossil fuel comparator emissions shall be the latest available actual average emissions from the fossil part of petrol and diesel consumed in the Community as reported under Directive 98/70/EC. If no such data are available, the value used shall be $83.8 \mathrm{~g} \mathrm{CO}_{2}$ eq/MJ [13]. Table 4 illustrates the GHG savings for both biofuels using the previous default value for conventional diesel.

These values show that policy objectives can be achieved when theoretical data of the processes are taken into account. This gives an idea of the real possibility of compliance with the Directive. Nevertheless, in order to certify a new biofuel in terms of reducing GHG emissions and, therefore, compliance with the Directive, original data of the whole products and processes involved must be submitted. In case that actual data source
Table 3. GHG emissions by stage for HVO and FAME (g $\left.\mathrm{CO}_{2} \mathrm{eq} / \mathrm{MJ}\right)$

\begin{tabular}{lcc}
\multicolumn{1}{c}{ Phase } & FAME & HVO \\
\hline Seed farming & 5.87 & 4.96 \\
Oil extraction & 7.73 & 6.54 \\
Oil refining & 0.40 & 0.34 \\
Oil transesterification & 5.05 & - \\
Oil hydrotreating & - & 4.48 \\
Transports & 4.18 & 3.98 \\
Combustion & 0 & 0 \\
TOTAL & $\mathbf{2 3 . 2 3}$ & $\mathbf{2 0 . 3 0}$ \\
\hline
\end{tabular}

Table 4. Percentage of GHG savings for FAME and HVO

\begin{tabular}{lcc}
\hline & FAME & HVO \\
\hline \% GHG savings & 72.30 & 75.78 \\
\hline
\end{tabular}

is not available, the Directive states typical and default values for agricultural and processing systems.

\section{Conclusions}

This work focused on the theoretical environmental performance comparison of two different processes to obtain biofuels from vegetable oil: hydrotreatment versus transesterification. The products obtained in each case are called HVO and FAME, respectively. It has been shown that the hydrotreating process could achieve good environmental performance in terms of GHG emissions, from theoretical data. Furthermore, the possibility of producing $\mathrm{HVO}$ is feasible and it does not require the construction of any new infrastructure, because it could be manufactured in oil refineries. However, optimization operations of the hydrotreatment unit should be carried out, since the chemical reaction forms $\mathrm{CO}$ and $\mathrm{CO}_{2}$ gases that could damage the catalyser. Moreover, a thermal balance should be done in the furnace due to the exothermic performance of the hydrogenation.

Finally, a theoretical compliance with European Directive 2009/28/EC has been shown due to the percentage of GHG savings in the entire life cycle of the biofuels. Nonetheless, original data of the whole products and processes involved are necessary in order to obtain the final policy certification.

\section{Perspectives and Future Works}

The first commercial scale HVO plant with a capacity of 
170 Mtons per year (3800 bbl per day) was started up in 2007 at Neste Oil's Porvoo oil refinery in Finland. This technology is based on a separate unit at an oil refinery site while at the same time using existing logistics, quality-control laboratories, and energy plant. A separate unit like this can be optimized and run without risking the refinery units, which may be a problem if bio-oils are fed into existing refinery units as blended with fossil feeds [2].

Currently, Spanish oil company Repsol is developing some projects to demonstrate the technical feasibility of the production of biofuels at an industrial scale, through co-processing of vegetable oils with fossil fuel in hydrotreatment units. A theoretical study from Garraín et al. [14] has been shown that co-processing would be feasible from the environmental point of view against other biofuel production processes, such as transesterification or separately hydrotreatment.

Two first industrial-scale demonstrations have been completed. The first, as indicated in the oil company, was positive, since the product obtained has suitable properties, including high-cetane, low density and ultralow sulphur. Due to these sterling properties, the obtained product could be fitted on the production of diesel, complementing the addition of seven percent of biodiesel that is currently allowed to use in conventional diesel. Second test was better because of optimizing operational factors and energy consumption associated with the production. The new product had identical properties as the first renewable diesel.

At present (July 2010), Energy System Analysis Unit from CIEMAT is working on calculating the environmental impacts of these new products, in order to reveal the 'green' benefit over other biofuels and their corresponding production processes.

\section{REFERENCES}

[1] H. Aatola, M. Larmi, T. Sarjovaara and S. Mikkonen, "Hydrotreated Vegetable oil (HVO) as a Renewable Diesel fuel: Trade-Off between NOx, Particulate Emission, and Fuel Consumption of Heavy Duty Engine," Helsinki University of Technology \& Neste Oil, Finland, 2008.

[2] R. Marinangeli, T. Marker, J. Petri, T. Kalnes, M. McCall, D. Mackowiak, B. Jerosky, B. Reagan, L. Nemeth, M. Krawczyk, S. Czernik, D. Elliott and D. Shonnard, "Opportunities for Biorenewables in Oil Refineries," Final Technical Report DE-FG36-05GO15085 from UOP LLC to U.S. Department of Energy, Des Plaines, 2005.

[3] T. Kalnes, T. Marker and D. R. Shonnard, "Green Diesel: A Second Generation Biofuel," International Journal of
Chemical Reactor Engineering, Vol. 5, A48, 2007.

[4] ISO 14040:2006 Environmental management-Life cycle assessment - Principles and framework.

[5] ISO 14044:2006 Environmental management-Life cycle assessment-Requirements and guidelines.

[6] J. A. Hilbert, L. B. Donato, J. Muzio and I. Huerga, "Comparative Analysis of Energetic Consumption and Greenhouse Gas Emissions from the Production of Biodiesel from Soy under Conventional and no Till Farming Systems," Boletín n ${ }^{\circ}$ 6, Doc N IIR-BC-INF-06-09, INTA, Argentina, 2009.

[7] Y. Lechón, H. Cabal, C. de la Rúa, C. Lago, L. Izquierdo, R. Sáez and M. Fernández, "Análisis del ciclo de vida de combustibles alternativos para el transporte. Fase II: Análisis del ciclo de vida comparativo del biodiésel y del diésel," Centro de Publicaciones-Secretaría Gral. TécnicaMinisterio de Medio Ambiente, Madrid, 2006.

[8] G. Reinhardt, S. O. Gärtner, H. Helms and N. Rettenmaier, "An Assessment of Energy and Greenhouse Gases of NExBTL," Final Report from Institute for Energy and Environmental Research Heidelberg GmbH (ifeu) by order of the Neste Oil Corporation (Porvoo, Finland), Heidelberg, 2006.

[9] R. Dones, C. Bauer, R. Bollinger, B. Burger, M. Faist Emmenegger, R. Frischknecht, T. Heck, N. Jungbluth, A. Röder and M. Tuschsmid, "Life Cycle Inventories of Energy Systems: Results for Current Systems in Switzerland and other UCTE Countries," Ecoinvent report No. 5, Paul Scherrer Institut Villigen, Swiss Centre for Life Cycle Inventories, Dübendorf, Switzerland, 2007.

[10] JEC, "Well-to-Wheels Analysis of Future Automotive Fuels and Powertrains in the European Context, Well-toWheels Report, Version 2c," CONCAWE/EUCAR/ECJRC-IES Report, 2007.

[11] PRé “SimaPro ${ }^{\circledR}$ 7.1", PRé Consultants, 2007, Amersfoort, The Netherlands. http://www.pre.nl

[12] J. B. Guinée, "Handbook of Life Cycle AssessmentOperational Guide to the ISO Standards," Kluwer Academic Publishers, Dordrecht, 2002.

[13] Directive 2009/28/EC of the European Parliament and the Council of 23 April 2009 on the promotion of the use of energy from renewable sources and amending and subsequently repealing Directives 2001/77/EC and 2003/ 30/EC, 05/06/2009, Official Journal of the European Union.

[14] D. Garraín, I. Herrera, C. Lago, Y. Lechón and R. Sáez, "Viabilidad Medioambiental del Co-Procesamiento de Aceites Vegetales en Unidades de Hidrotratamiento Para Obtener Biocarburantes en el Marco del ACV," XIV International Conference on Project Engineering, Madrid, 2010. 